\title{
Surface mass balance in east Dronning Maud Land, Antarctica, observed by Japanese Antarctic Research Expeditions
}

\author{
SHLHEI TAKAHASHI, \\ Kitami Inslitute of Technology, Kilami, Hokkaido 090, Japan
}

\author{
YUTAKA AgETA, \\ Institute for Hydrospheric-Atmospheric Science, Nagoya Universily, Nagoya 464-01, Japan
}

Yoshiyuki Fujil And Okitsugd Watanabe
kational Institute of Polar Research, Itabashi, Tokyo 173, Japan

\begin{abstract}
ABSTR $\triangle C T$. The surface mass balance in east Dronning Maud Land has been observed mainly by means of the snow-stake method. The surface mass balance generally decreased with distance from the coast; from more than $250 \mathrm{~mm}$ a ${ }^{1}$ in the coastal region to less than $50 \mathrm{~mm} \mathrm{a}^{-1}$ in the inland region higher than $3500 \mathrm{~m}$ in altitudc. At Mizuho Station (2230 ma.s.l.), the sublimation was about $50 \mathrm{~mm}$ a ${ }^{1}$. precipitation was between 140 and $260 \mathrm{~mm} \mathrm{a}^{-1}$, and the loss from the surface by the redistribution was estimated to be about $100 \mathrm{mma}{ }^{1}$, which agrees with the surface mass balance estimated as $70 \mathrm{~mm} \mathrm{a}^{-1}$ from the grain-growth rate. Around the mountainous area, the balance was small or in some cases negative, where a bare-ice field has developed. In the inland area, 3000-3200 $\mathrm{m}$ a.s.l., the surface mass balance was less than $50 \mathrm{mma}{ }^{1}$, i.e. lower than in the surrounding areas. This low massbalance area can be explained by redistribution by the drifting snow. The whole mass input in five drainage basins with a total area of $620 \times 10^{3} \mathrm{~km}^{2}$ is $61.2 \mathrm{Gton} \mathrm{l}^{1}$ and the mean surface mass balance is $99 \mathrm{~mm} \mathrm{a}^{-1}$.
\end{abstract}

\section{INTRODUCTION}

Japanese Antarctic Research Expeditions (JARE; have observed the surface mass balance along many traverse routcs in the area from west Enderby Land to east Dronning Maud Land, East Antarctica, for 25 years (Fig. 1). Along the route between Syowa Station $\left(69^{\circ} 00^{\prime} \mathrm{S}, 39^{\circ} 35^{\prime} \mathrm{E}, 20 \mathrm{~m}\right.$ a.s.l.) and Mizuho Station $\left(70^{\circ} 42^{\prime} \mathrm{S}, 44^{\circ} 20^{\prime} \mathrm{E}, 2230 \mathrm{~m}\right.$ a.s.l. $)$, the surface mass balance has been observed every year by the snow-stakc method since 1968. In the Glaciological Research Program on Mizuho Plateau from 1969 to 1975, surface mass-balance observations were carried out from the Yamato Mountains area in the west to the Sandercock Nunataks in the east. In the Glaciological Research Program in east Dronning Maud Land from 1982 to 1987, the observations were carried out over a wider area from the Sor-Rondane mountains area to the Mizuho Plateau including the highest point in east Dronning Maud Land, Dome F ( $77^{\circ} 22^{\prime} \mathrm{S}, 39^{\circ} 37^{\prime} \mathrm{E}, 3800 \mathrm{~m}$ a.s.l. $)$. All these surface mass-balance data have been compiled to obtain the distribution of surface mass balance in east Dronning Maud Land.

\section{SNOW ACCUMULATION OBSERVED BY THE SNOW-STAKE METHOD}

At 2349 points along the 16 traverse routes on the ice sheet, snow stakes $2.5 \mathrm{~m}$ long were usually placed at intervals of $2 \mathrm{~km}$ (Table 1). Their height change with time was measured to determine snow accumulation.

The surface mass balance was obtained by multiplying snow density by the accumulation. The surfacc mass balance along the route from $\$ 16 \quad 69^{\circ} 02^{\prime} \mathrm{S}, 40^{\circ} 03^{\prime} \mathrm{E}$, $553 \mathrm{~m}$ a.s.1.) near Syowa Station to Mizuho Station from 1971 to 1980 is shown in Figure 2. The route passes through threc routcs of $\mathrm{S}, \mathrm{H}$ and $\mathrm{Z}$. Though the annual accumulation varied year to year, we can see the regional characteristics along the traverse route. There is a region where the surfacc mass balance was constantly small or negative every year, as at distances of about 180 and $230 \mathrm{~km}$ from $\mathrm{S} 16$, while it was constantly large in the area between 50 and $150 \mathrm{~km}$.

The snow-stake method for surface mass balance is easy to carry out but there is a difficult problem concerning variability with time and place. On the katabatic wind slope of the ice sheet, the wind redis- 


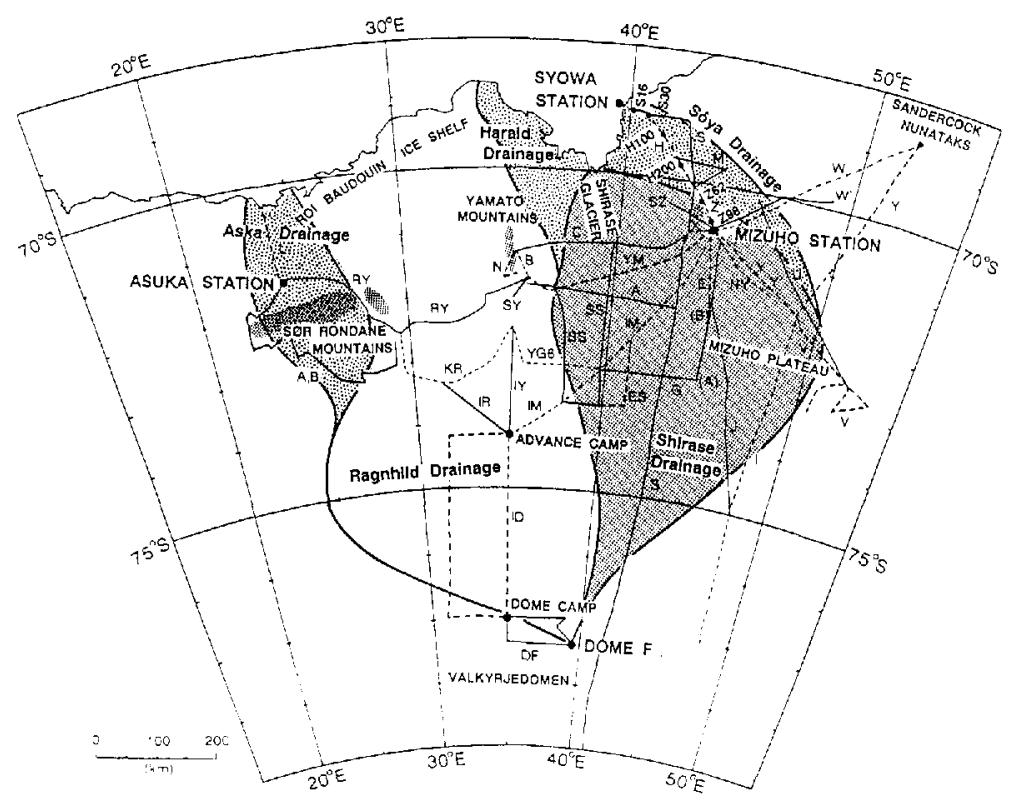

Fig. 1. Tiaverse routes on east Dronning Maud Land by .Japanese Antartic Research Expedilions (JARE). The observalion area is divided into five drainage basins, Asuka, Ragnhild, Harald, Shirase and Sôya Drainage Basins.

tributes the snow accumulation forming sastrugi and dunes. 'lo avoid such variability as much as possible, we should measure the surface mass balance for a long period, or obtain a mean value among many observation points.

The cumulative snow accumulation along the route between Syowa Station and Mizuho Station from 1971 to 1986 is shown in Figure 3. In the coast zone between S16

Table 1. Traverse routes for snow accumulation obsercation

\begin{tabular}{c} 
Route \\
$\mathrm{km}$ \\
\hline
\end{tabular}

\begin{tabular}{lccr}
$\mathrm{S}$ & $16-974$ & 2 & 710 \\
$\mathrm{H}$ & $3-306$ & $0.5-1$ & 266 \\
$\mathrm{Z}$ & $1-103$ & 1 & 101 \\
$\mathrm{~A}$ & $1 \cdots 164$ & 4 & 130 \\
$\mathrm{G}$ & $2-26$ & 2 & 13 \\
$\mathrm{Y}$ & $100-200$ & 5 & 18 \\
$\mathrm{~V}$ & $10-140$ & 5 & 23 \\
$\mathrm{~W}$ & 5100 & 5 & 19 \\
$\mathrm{YM}$ & $0-179$ & 2 & 179 \\
$\mathrm{SS}$ & $0-150$ & 2 & 150 \\
$\mathrm{NY}$ & 2100 & 2 & 50 \\
$\mathrm{IM}$ & $2-252$ & 2 & 248 \\
$\mathrm{ID}$ & $1-43$ & 2 & 39 \\
KR & $1-75$ & 2 & 74 \\
$\mathrm{RY}$ & $1-258$ & 2 & 258 \\
$\mathrm{~L}$ & $2-120$ & 2 & 60 \\
& & (Total 2349 points) \\
\hline
\end{tabular}

and $\mathrm{S} 30$, the snow accumulation was large and depended on altitude; it was largest at $\$ 20 \quad(653 \mathrm{~m}$ a.s.l.). In the accumulation zone between $\mathrm{H} 100$ and $\mathrm{H} 200$

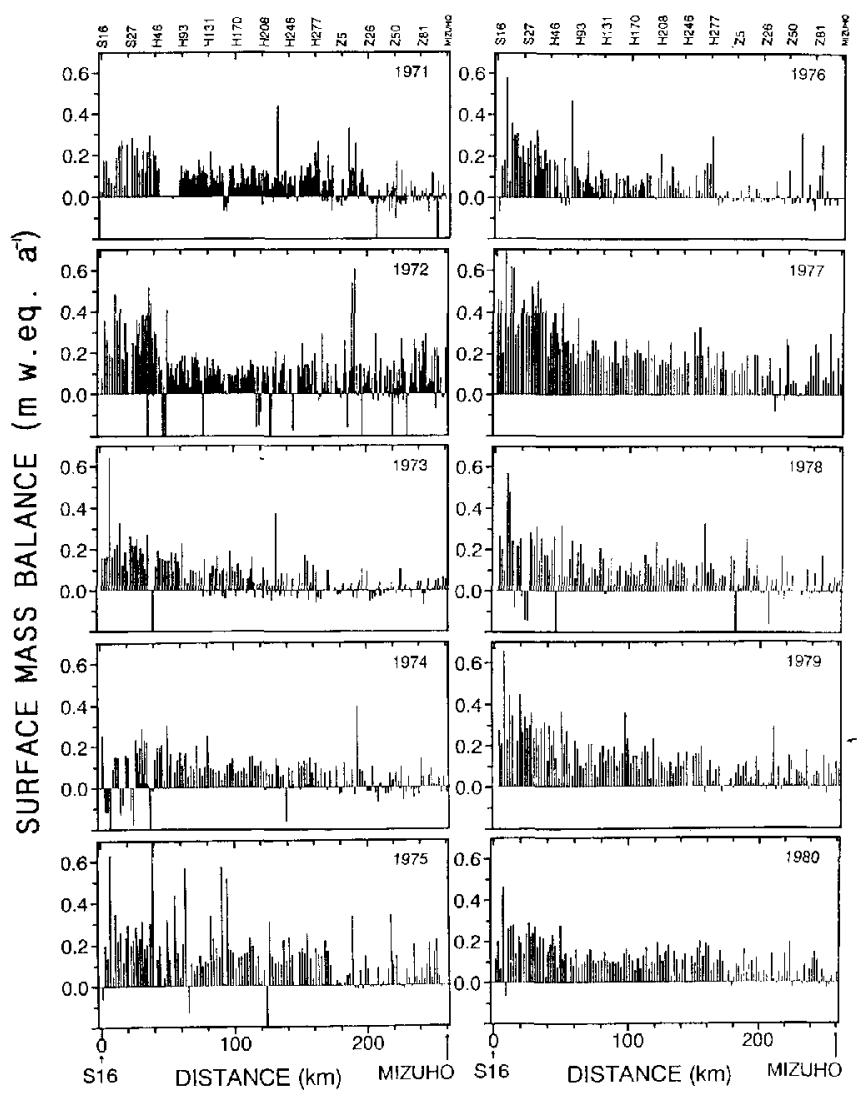

Fig. 2. Surface mass balance observed by the snow-stake method along a route from $S 16\left(69^{\circ} 02^{\prime} S, 40^{\circ} 03^{\prime} \mathrm{E}\right.$, 553 ma.s.l.) to Mizuho Slation $\left(70^{\circ} 42 \mathrm{~S}, 44^{\circ} 20^{\prime} \mathrm{E}\right.$, 2230 m a.s.l.). 


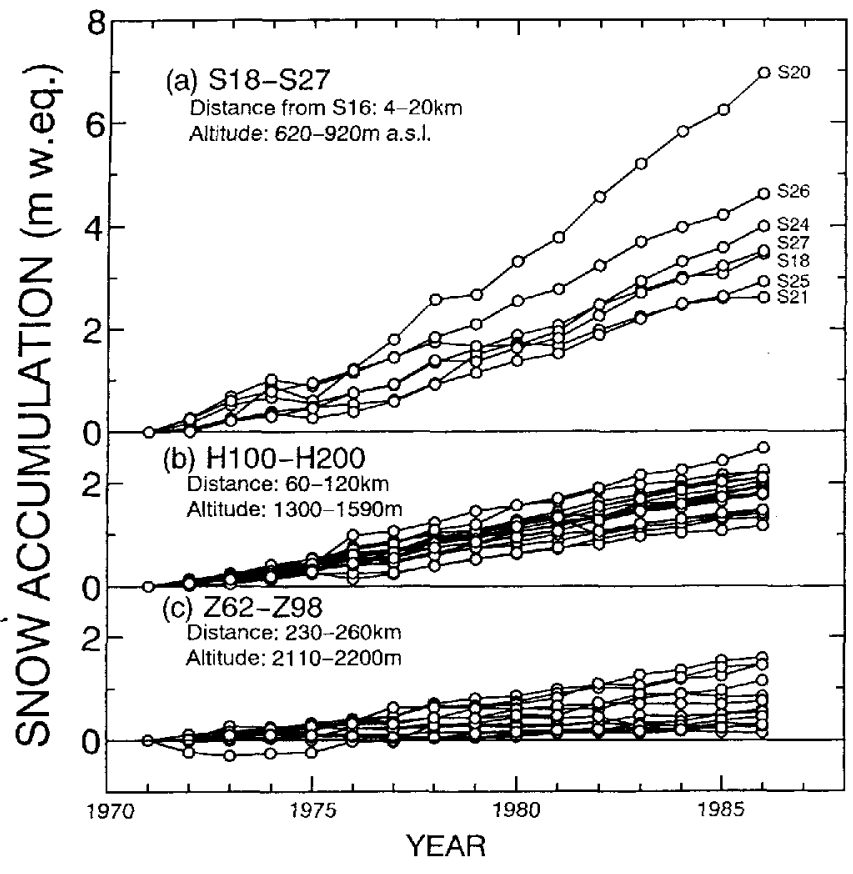

Fig. 3. Cumulative snow accumulation observed by the snow-stake method from 1971 to 1986 along route $S-H$ Z. (a) In the coastal region along $\$ 18 \quad \$ 27$ (620-920 ma.s.l.); (b) In the accumulation region along $\mathrm{H100} \mathrm{H} 200(13001590 \mathrm{~m})$; (c) In the katabatic wind region along $Z 622,298(2110-2200 \mathrm{~m})$.

$1590 \mathrm{~m}$ a.s.1.), the accumulation increased steadily with only minor fluctuations. In the strong katabatic wind zone between Z62 and Z98 (2110-2200ma.s.l.), the accumulation was small. Thus, the cumulative snow accumulation for more than loyears can show the regional features of snow accumulation.

\section{SNOW ACGUMULATION OBSERVED BY OTHER METHODS}

Gross $\beta$ activity was measured on melt samples of icc cores at intervals of about $10 \mathrm{~cm}$ depth. In the gross $\beta$ profile, large activity levels originating from nuclear experiments appcar in layers formed in 1955 and 1965 (Picciotto and Wilgain, 1963; Crozaz, 1969). The snow accumulation can be estimated from the depths of these reference layers. This estimation was made at nine points in east Dronning Maud Land (Table 2).

From the vertical profile of grain-size in an ice core, Narita and Maeno (1979) tried to estimate the snowaccumulation rate. Taking into account the growth rate of ice crystal grains under a load, they obtained the net annual accumulation of $70 \mathrm{~mm}$ a $^{1}$ at Mizuho Station. This method needs a temperature profile and an assumption of constant accumulation rate but it is useful in a region where the seasonal variation cannot be recognized.

\section{SNOW DENSITY}

The surface-snow density is necessary to obtain surface mass balance from snow accumulation. When JARE made a traverse from Syowa Station to Plateau Station along route $\mathrm{S}$ in 1967-68, mean snow density from the surface to $2 \mathrm{~m}$ depth was measured at intervals of about $10 \mathrm{~km}$ (Fujiwara and Endo, 1971). As shown in Figure 4, at an altitude between 1500 and $2700 \mathrm{~m}$ the density was constant, about $416 \mathrm{~kg} \mathrm{~m}^{-3}$ on avcrage. It decreased from 900 to $1500 \mathrm{~m}$ elevation and decreased in the inland region above $2700 \mathrm{~m}$ a.s.l.

The snow density depends on many factors, such as snow-crystal type, accumulation rate, lapse time after dcposit, temperature, humidity, wind speed and other meteorological conditions. It is difficult to represent the snow density as a function of all these factors. To simplify the equation, the temperature is considered to be the main variable related to snow density. If the density varies mainly with temperature, the dependence of snow density on altitude can be explained by the lowering of temperature with altitude. Therefore, as a rough approximation, we used the simple relation between snow density and altitude shown in Figure 4 (a solid line) to obtain surface mass balance.

Table 2. Surface mass balance (in w.e.) estimated from gross $\beta$ radioactivity and tritium profiles

\begin{tabular}{|c|c|c|c|c|c|c|}
\hline \multirow[t]{2}{*}{ Location } & Latitude & Longitude & Elevation & $\begin{array}{c}\text { Sampling } \\
\text { date }\end{array}$ & Balance & \multirow[t]{2}{*}{ Method } \\
\hline & $S$ & $\mathrm{E}$ & $\mathrm{m}$ & & $\mathrm{mma}^{-1}$ & \\
\hline $\mathrm{S} 25$ & $69^{\circ} 02^{\prime} 12^{\prime \prime}$ & $40^{\circ} 27^{\prime} 00^{\prime \prime}$ & 844 & Dec 1985 & 240 & $\beta$ \\
\hline $\mathrm{H} 260$ & $69^{\circ} 52^{\prime} 36^{\prime \prime}$ & $42^{\prime} 43^{\prime} 06^{\prime \prime}$ & 1748 & May 1985 & 122 & $\beta$ \\
\hline NY28 & $70^{\circ} 47^{\prime} 46^{\prime \prime}$ & $44^{\prime} 39^{\prime} 35^{\prime \prime}$ & 2337 & Dec 1985 & 72 & $\beta$ \\
\hline NY58 & $70^{\circ} 56^{\prime} 26^{\prime \prime}$ & $45^{\circ} 08^{\prime} 53^{\prime \prime}$ & 2417 & Dec 1988 & 138 & $\beta$ \\
\hline NY122 & $71^{\circ} 25^{\prime} 22^{\prime \prime}$ & $46^{\circ} 57^{\prime} 10^{\prime \prime}$ & 2699 & Dec 1988 & 121 & $\beta$ \\
\hline E50 & $71^{\circ} 12^{\prime} 38^{\prime \prime}$ & $44^{\circ} 30^{\prime} 25^{\prime \prime}$ & 2439 & Nov 1988 & 85 & $\beta$ \\
\hline ID 315 & $75^{\circ} 00^{\prime} 09^{\prime \prime}$ & $31^{\circ} 29^{\prime} 21^{\prime \prime}$ & 3414 & Dec 1985 & 68 & $\beta$ \\
\hline ID259 & $76^{\circ} 00^{\prime} 12^{\prime \prime}$ & $31^{\circ} 23^{\prime} 17^{\prime \prime}$ & 3648 & Dec 1985 & 35 & $\beta$ \\
\hline ID 155 & $77^{\circ} 00^{\prime} 01^{\prime \prime}$ & $35^{\circ} 00^{\prime} 00^{\prime \prime}$ & 3761 & Dec 1985 & 33 & Tritium \\
\hline
\end{tabular}




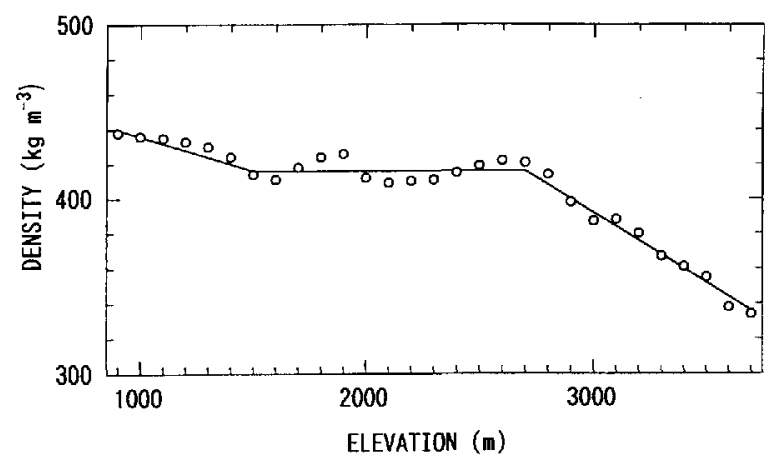

Fig. 4. Snow density versus elevation along route $S$ from $S 31$ ( $69^{\circ} 03^{\prime} \mathrm{S}, 40^{\circ} 43^{\prime} \mathrm{E}, 961$ ma.s.l.) lo $S 654$ ( $79^{\circ} 06^{\circ} \mathrm{S}$, $40^{\circ} 33^{\prime} \mathrm{E}, 3618 \mathrm{~m}$ a.s.l.). Circles are mean density every $100 \mathrm{~m}$ in altitude. The solid line shows the simplified relation used to estimate water equivalent of surface mass balance from snow accumulation and elevation.

\section{PREGIPITATION}

Precipitation in polar regions is difficult to measurc in an ordinary way, because a snow-gauge is not reliable owing to the strong katabatic winds.

At Mizuho Station, precipitation was measured during a drifting-snow observation. Assuming that all the snow was due to precipitation at $30 \mathrm{~m}$ height, Kobayashi and others (1985) obtained a value of $140 \mathrm{mma}^{\mathrm{l}}$ for the annual precipitation in 1980 from the snow-flux observation. By the same method, Takahashi (1985) obtained $260 \mathrm{~mm} \mathrm{a}^{\prime}$ as the precipitation rate in 1982 and $230 \mathrm{~mm} \mathrm{a}^{-1}$ by distinguishing prccipitation from the drift flux at $1 \mathrm{~m}$ height (Fig. 5). Thus, the average precipitation was roughly $200 \mathrm{~mm} \mathrm{a}^{-1}$ at Mizuho Station, within a wide range between 100 and 300 $\mathrm{mm} \mathrm{a}^{-1}$, whereas the snow accumulation was estimated as $70 \mathrm{mma}^{1}$ by grain-growth rate (Narita and Maeno, 1979).

\section{SUBLIMATION FROM THE SURFAGE}

While ablation due to melting is limited to the coastal

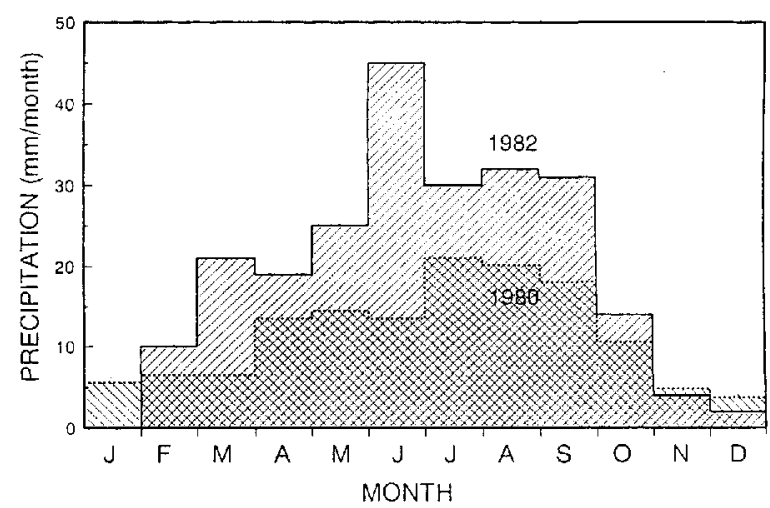

Fig. 5. Seasonal variation of precipitation at Mizuho Station (2230 ma.s.l.). Annual precipitation was 140 $m m a^{-1}$ in 1980 (Kobayashi and others, 1985) and $230 \mathrm{mma}^{-1}$ in 1992 (Takahashi, 1985).

region, sublimation from ice to water vapor occurs all over the ice sheet and plays an important role in the surface mass balance as a negative component.

Fujii and Kusunoki (1982) obtained an annual sublimation of about $50 \mathrm{mma}^{1}$ as the loss at Mizuho Station for the period 1977-88 using the stake method and weighing an evaporimeter filled with ice. Takahashi and others (1992) obtained an annual sublimation of $52 \mathrm{~mm} \mathrm{a}^{-1}$ at Mizuho Station in 1982 by the cvaporimeter method. In the seasonal variation, a large amount of sublimation occurs in summer from October to February, while much smaller amounts of sublimation and solidification alternate, with net solidification, in winter.

On a bare-ice surface, sublimation causcs a large loss of ice from the surface. At Seal Rock in the Sor-Rondane, the sublimation was $200-280 \mathrm{~mm} \mathrm{a}^{-1}$. This large sublimation was explained by the low albedo of the bare-ice surface (Takahashi and others, 1992).

\section{REDISTRIBUTION BY DRIFTING SNOW}

The surface mass balance tends to depend on the ice-sheet topography. In Figure 6, the surface mass balance measured by the snow-stake method is shown on a

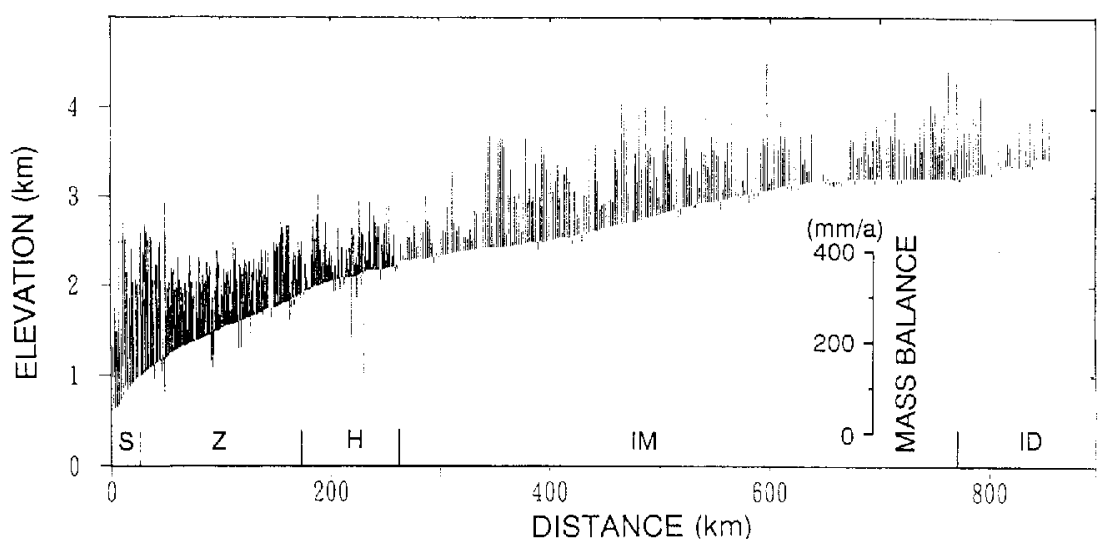

Fig. 6. Surface mass balance along route $S-H-Z-I M-I D$. Surface mass balance is expressed as bars on a cross-sectional profile of the ice sheet. Positive values are plotted above the ice sheet surface and negative values below the surface. 


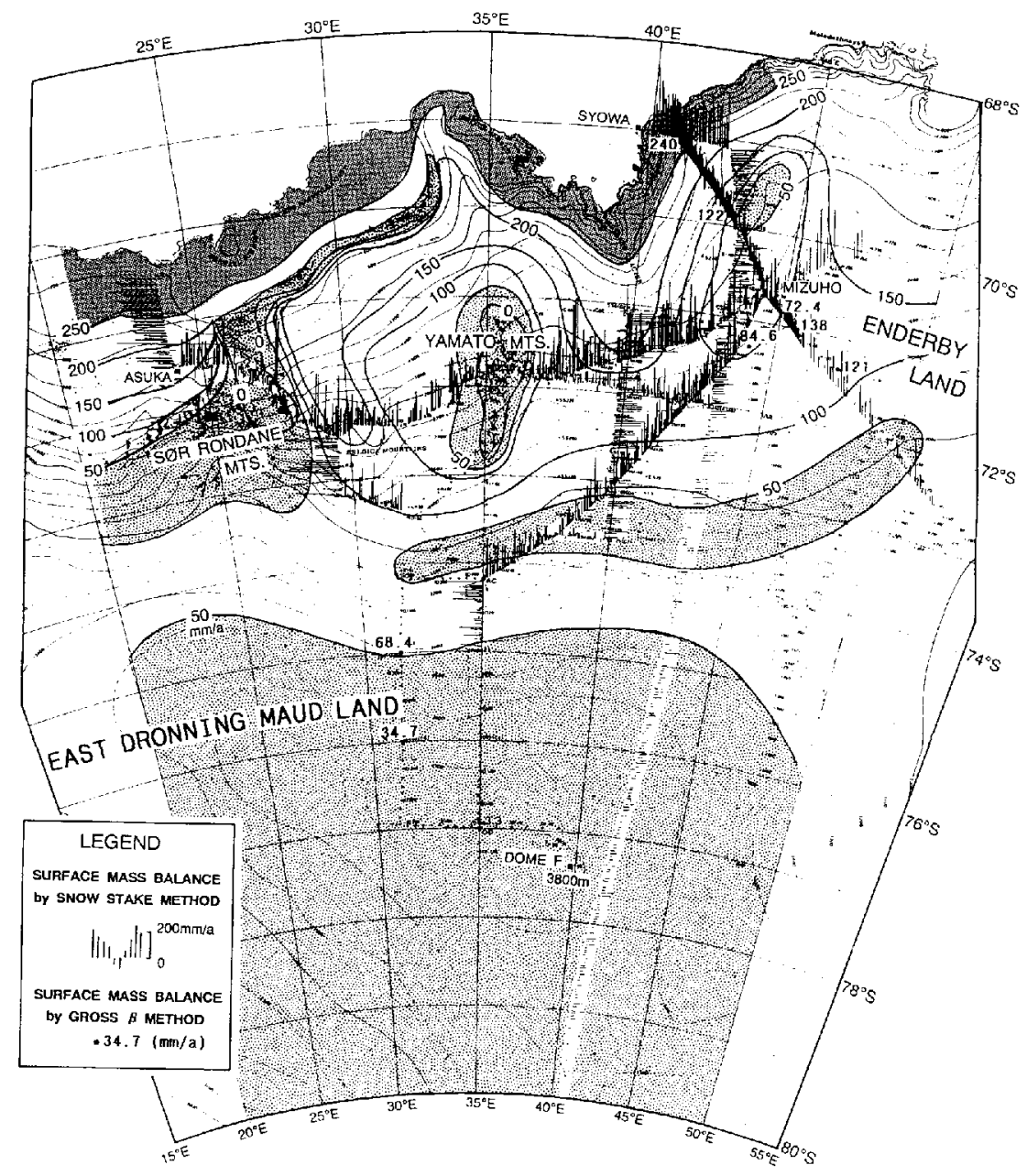

Fig. 7. Surface mass balance in east Dronning Maud Land. Solid lines are isolines of surface mass balance (mma ${ }^{-1}$ in w'ater equivalent). Bars show snow-surface mass balance measured by the snow-slake method at each stake. Values at solid circles are surface mass balance obtained from gross $\beta$ activity and tritium profiles shown in Table 2.

cross-scctional profile of the ice sheet. On a large scale, the balance is small on the convex topography in the zones $250-350 \mathrm{~km}$ and $640-660 \mathrm{~km}$ from the coast, and large on the concave topography from 350 to $550 \mathrm{~km}$. The same tendency is secn on a small scale over a short distance of $10-30 \mathrm{~km}$; the balance was small on convex arcas at 260 and $650 \mathrm{~km}$. A similar relation between local mass balance and topography has been reported in other inland areas of Antarctica (Schytt, 1955; Swithinbank, 1958; Black and Budd, 1964; Gow and others, 1972; Whillans, 1975).

This dependence of surface mass balance on topography is explained by redistribution of snow accumulation as follows. On the slope of the ice sheet in Antarctica, katabatic winds are formed by the gravitational force of cold air masses and gencrate drifting snow throughout the year. If the wind speed is accelerated on convex topography because the slope increases, the drift-transport rate increases along a wind-stream line and the surface snow layer is eroded. In other words, when considering the two-dimensional wind flow, horizontal divergence of drifting snow causes the erosion of surface snow. The opposite happens on concave topography; the horizontal convergence of drifting snow causes snow to deposit on the surface.

Takahashi and others (1988) calculated the horizontal divergence of drifting snow from the ice-sheet topography on Mizuho Platcau, using a relationship between drifttransport rate and wind speed as a function of surfacc slope. The results explain the existence of the bare-ice fields around the region south of the Yamato Mountains.

At Mizuho Station, the loss due to horizontal divergence is cstimated to be about $100 \mathrm{mma}$, which agrees with the precipitation of $140-260 \mathrm{mma}$ ', sublimation of $50 \mathrm{~mm} \mathrm{a}^{-1}$ and surface mass balance from grain growth of $70 \mathrm{~mm} \mathrm{a}^{-1}$.

\section{SURFACE MASS BALANGE IN EAST DRONNING MAUD LAND}

The snow accumulation measured by the snow-stake method at more than 2300 points along 16 traverse routes is shown in Figure 7 as bar lengths. The results of gross $\beta$ activity and tritium analysis are also plotted in this figure. From thesc data, the isolines of surface mass balance were drawn (Fig. 7).

Generally, the surface mass balance decreased with distance from the coast: from more than $250 \mathrm{mma}^{1}$ (w.e.) in the coastal region to less than $50 \mathrm{~mm} \mathrm{a}^{-1}$ in the inland region more than $600 \mathrm{~km}$ from the coast and higher than $3500 \mathrm{~m}$ altitude.

In the vicinity of mountainous areas, the surface mass balance was negative, i.e. a bare-icc surface is present. On 

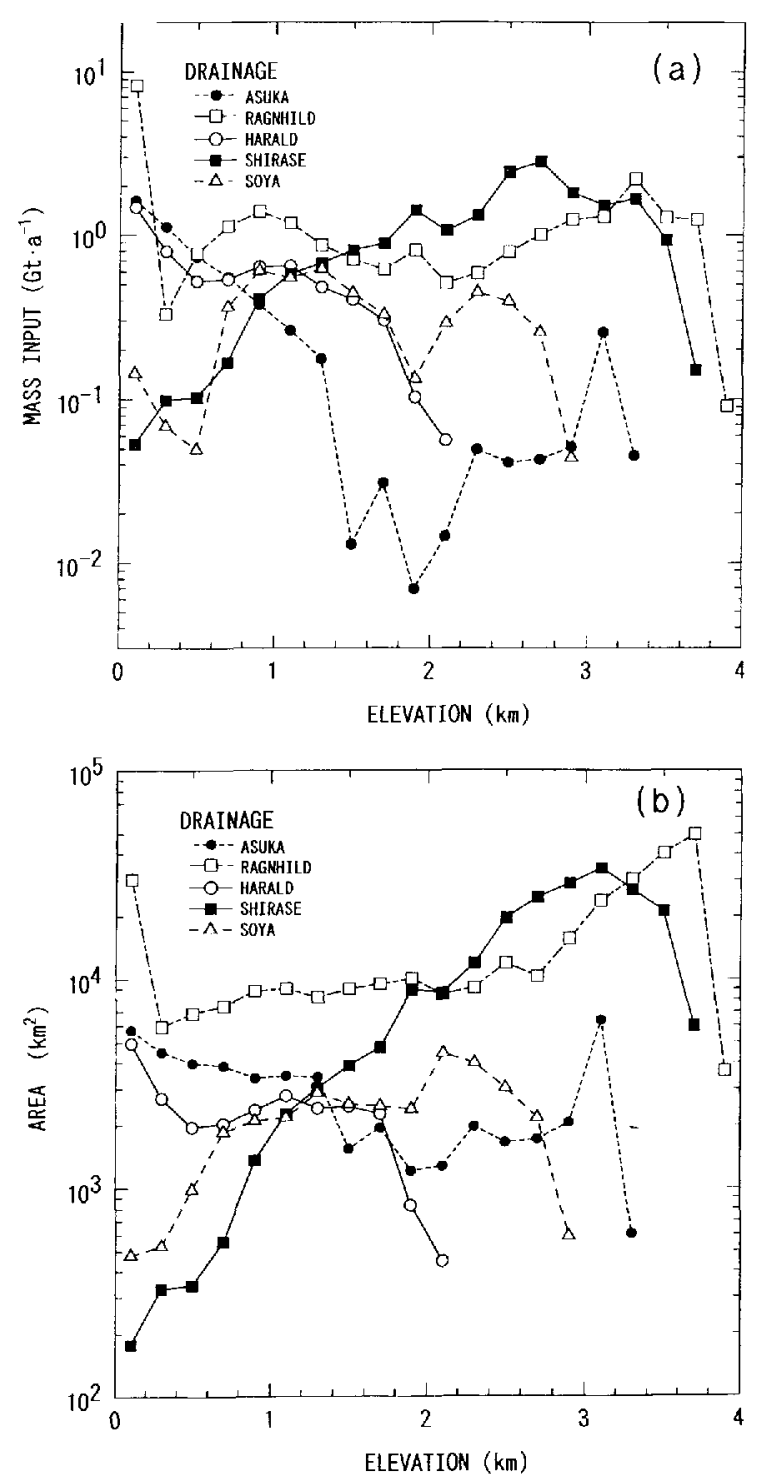

Fig. 8. Mass inpul (a) and area (b) bounded by every $200 \mathrm{~m}$ contour line against elevation in the five drainage basins in east Dronning Maud Land.

the bare-ice surface, loss by sublimation prevails and the balance shows large negative values (Takahashi and others, 1988).

In the inland area between 3000 and $3200 \mathrm{~m}$ altitude, the surface mass balance shows a local minimum, less than $50 \mathrm{~mm} \mathrm{a}$, although there are no mountains in the neighborhood. This low-balance area can be explained by redistribution of snow accumulation by drifting.

Giovinetto and Bull (1987) have compiled surface mass-balance data for the whole icc sheet of Antarctica. In their results, the balance around Yamato Mountains was taken into account but recent information on this area was not used, because the data had not been published at that time. The most recent results for the surface mass balance around east Dronning Maud Land arc shown in Figure 7.

The observed area is divided in to five drainage basins, Asuka, Ragnhild, Harald, Shirase and Sôya drainage basins, based on the surface contours (Fig. 1). Mass input into these drainage basins was estimated from the results of the surface mass balance shown in Figure 7 . In each drainage basin, area size and mass input were calculated
Table 3. Area, mass inpul, surface mass balance in five drainage basins in east Dronning Maud Land

\begin{tabular}{lrrr}
\hline Drainage & Area & Mass input & $\begin{array}{c}\text { Surface mass } \\
\text { balance }\end{array}$ \\
& $\times 10^{3} \mathrm{~km}^{2}$ & $\mathrm{Gta}^{1}$ & $\mathrm{~mm} \mathrm{a}^{1}$ \\
\hline Asuka & 48.5 & 5.4 & 111 \\
Ragnhild & 307.5 & 26.3 & 85 \\
Harald & 25.1 & 6.0 & 237 \\
Shirase & 206.6 & 18.9 & 91 \\
Sôya & 32.5 & 4.7 & 145 \\
T'otal & 620.2 & 61.2 & 99 \\
& & & \\
\hline
\end{tabular}

for zones between every $200 \mathrm{~m}$ contour line (Fig. 8) and integrated over the whole basin. The integrated results are listed in Table 3. For all the drainage basins, the mass input over an area of $620 \times 10^{3} \mathrm{~km}^{2}$ is $61.2 \mathrm{Gton} \mathrm{a}{ }^{1}$ and the mean surface mass balance is $99 \mathrm{mma}^{-1}$. 'The variation of surface mass balance with elevation is shown in Figure 9.

In the Shirase drainage basin, the mass input is 18.9 Gton $\mathrm{a}^{-1}$ over an area of $207 \times 10^{3} \mathrm{~km}^{2}$. This input is

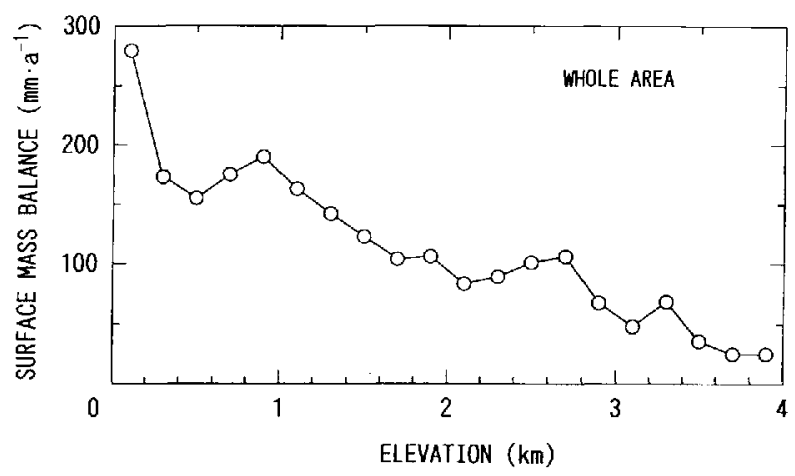

Fig. 9. Mean surface mass balance bounded by every $200 \mathrm{~m}$ contour line against elevation. The surface mass balance. was calculated for the whole area of the five drainage basins.

larger than the icc-stream discharge from Shirase Glacier, 12.0 13.2 Gton a ${ }^{1}$ (Nakawo and others, 1978). These results conflict with the survey result that the ice sheet in this area is thinning at a rate of $70 \mathrm{~cm} \mathrm{a}^{-1}$ (Naruse, 1979). The reasons for this difference are not clear.

\section{ACKNOWLEDGEMENTS}

The authors wish to express thanks to the members of the Japanese Antarctic Research Expeditions who have made much effort to measure the snow-accumulation data along various traverse routes for long time periods. They are indebted to Professor O. Orheim, of the Norsk Polarinstitutt, Oslo, for his critical reading of the 
manuscript and to Dr K. Kamiyama of the National Institute of Polar Research, Tokyo, for providing the gross $\beta$ radioactivity data. 'This study was carricd out as part of the East Queen Maud Land Project.

\section{REFERENCES}

Black, H.P. and W. Budd. 1964. Accumulation in the region of Wilkes, Wilkes Land, Antarctica. 7. Glaciol., 5(37), 3-15.

Crozaz, G. 1969. Fission products in Antarctic snow, an additional reference level in January 1965. Farth Planet. Sci. Lett., 6(1), 6-8.

Fujii, Y, and K. Kusunoki. 1982. The role of sublimation and condensation in the formation of ice sheet surface at Mizuho Station, Antarctica. 7. Geophys. Res., 87(C6), 42934300.

Fujiwara, K. and Y. Endo. 1971. Preliminary report of glaciological studies. Fpn. Anlarcl. Res. Exped. Sci. Rep. Special Issue 2, 68-109.

Giovinetto, M. B. and C. Bull. 1987. Summary and analysis of surface mass balance compilations for Antarctica, 1960-1985. Ohio State Univ. Byrd Polar Res. Cenler. Rep. 1.

Gow, A.J., F. de Blander, G. Crozaz and E. Picciotto. 1972. Snow accumulation at "Byrd" station, Antarctica. F. Glaciol., 11(61), 59-64.

Kobayashi, S., N. Ishikawa and T. Ohata. 1985. Katabatic snow storms in stable atmospheric conditions at Mizuho Station, Antarctica. Ann. Glaciol., 6, 229231.

Nakawo, M., Y. Ageta and A. Yoshimura. 1978. Discharge of ice across the Soya Coast. Mem. Nalt. Inst. Polar Res. Speciat Issue 7, 235-244.
Narita, H. and N. Maeno. 1979. Growth rate of crystal grains in snow at Mizuho Station, Antarctica. Antarct. Rec. 67, 1117.

Naruse, R. 1979. Thinning of ice sheet in Mizuho Platcau, Fast Antarcica. J. Glaciol., 24(90), 45-52.

Picciotto, E. and S. Wilgain. 1963. Fission products in Antarctic snow, a reference level for measuring accumulation. 7. Gophys. Res., 68 21 ), 5965-5972.

Schytt, V. 1955. Glaciological investigations in the Thule Ramp area. SIPRE Rep. 28.

Swithinbank, C. 1958. Glaciology I. E. The regime of the ice sheet of westem Dronning Maud Land as shown by stake measurements. Noreegian-British-Swedish Antarctic Expedition, 1949-52. Sci. Results, 3, 121-144.

Takahashi, S. 1985. Estimation of precipitation from drifting snow observation at Mizuho Station in 1982. Mem. Natl. Inst. Polar Res. Special Issue 39, 123-131.

Takahashi, S., R. Naruse, M. Nakawo and S. Mae. 1988. A bare ice field in east Queen Maud Land, Antarctica, caused by horizontal divergence of drifting snow. Ann. Glaciol., 11, 156-160.

Takahashi, S., T. Endoh, N. Azuma and S. Meshida. 1992. Bare ice fields developed in the inland part of Antarctica. Procedings of the NIPR Symposium on Polar Meteorology and Glaciology 5, 128-139.

Whillans, I. M. 1975. Effect of inversion winds on topographic detail and mass balance on inland icc sheets. 7. Glaciol., 14(70), 85-90.

The accuracy of references in the lext and in this list is the responsibility of the authors, to whom queries should be addressed. 